\title{
LAND USE POLICY AREA (LUPA) CONCEPT MODEL
}

A.M.R. Abante ${ }^{1}$, C.G.R. Abante ${ }^{2}$, A.M. Mascariñas ${ }^{3}$, C.J.V. Cortez $^{3}$, M.A.B. Guiriba ${ }^{3}$, E.C. Alfane ${ }^{3}$, P.N. Rojas ${ }^{3}$, R.Sr. Dioneda ${ }^{3}$, D. Mirabete ${ }^{4}$, J.N. Bartolome $^{4}$, A.J.M. Maceres ${ }^{5}$, R. Garcia ${ }^{6}$, R.E. Bautista ${ }^{7}$, E.T.M. Livica ${ }^{8}$, N.L. Ibo $^{9}$, V. Orozco ${ }^{1}$, C.D.A. Bausing ${ }^{1}$

${ }^{1}$ Bicol University College of Engineering - anamarie.abante@ bicol-u.edu.ph ${ }^{2}$ Partido State University - cgrabante@gmail.com

${ }^{3}$ Bicol University Research, Development and Extension - ammascarinas@bicol-u.edu.ph , cjrvcortez@ bicol-u.edu.ph , mabguiriba@bicol-u.edu.ph, elizabeth.alfane@bicol-u.edu.ph, pnrojas@bicol-u.edu.ph, rsrdioneda@bicol-u.edu.ph

${ }^{4}$ Bicol University Institute of Design and Architecture - delfinjrmontejo.mirabete@bicol-u.edu.ph, jobelnabo.bartolome@bicol-u.edu.ph

${ }^{5}$ Bicol University College of Agriculture and Forestry - ajmmaceres@ bicol-u.edu.ph

${ }^{6}$ Bicol University College of Business Economics and Management - riza.garcia@bicol-u.edu.ph

${ }^{7}$ Bicol University College of Education - rebautista@bicol-u.edu.ph

${ }^{8}$ Bicol University College of Nursing - etmlivica@ bicol-u.edu.ph

${ }^{9}$ Bicol University - Jesse M. Robredo Institute of Governance and Development - nlibo@bicol-u.edu.ph

KEY WORDS: LUPA, IEM, IE-DPU, ecosystem, watershed, land use

\begin{abstract}
:
The paper presents a Land Use Policy Area (LUPA) Concept Model adding the three basic elements: (i) ecosystem-based land use regarded as the intersection of the ecosystem and land use elements, (ii) subwatershed-based land use as the intersection of the subwatershed and land use elements, and (iii) integrated environmental management is the intersection of the subwatershed and ecosystem elements regarded as the Integrated Ecosystem Development Planning Unit (IE-DPU). The basic (spatial) elements are mathematically expressed as the paired sets of the three main variables, namely: ecosystem (dependent), watershed (dependent) and land use (independent) variables. The challenging work in this study was the development of a geospatial information model for use in policy areas LUPA applying these variables. There are four steps applied to answer the research objective, these are: ecological zone assessment, ridge-to-reef watershed delineation, land and water use heads-up mapping, ecosystem-based land use overlay analysis, watershed-based land use overlay analysis, integrated environmental management overlay analysis, and LUPA overlay analysis. The concept model analysis steers the geospatial information modeling for LUPA which carried the intersections of the paired variables: ecosystem-based land use, subwatershed-based land use and integrated environmental management as variating inputs to process by extracting the science-based information (overlay output) which practically highlighted the LUPA classification: (i) Protection with $49.1 \%$ or $3858.2 \mathrm{Ha}$ of mangrove forest reserve and water use, (ii) Production areas with $46.5 \%$ or $3631.7 \mathrm{Ha}$ mostly agricultural and aquacultural areas, (iii) Settlement with $2.7 \%$ or $209.2 \mathrm{Ha}$ of urban and urban uses, and (iv) Infrastructure with $1.5 \%$ or $116.7 \mathrm{Ha}$ of development. The authors concluded that land use policy areas will relatively change as land use changes which is also seen reliant on the impacts of climate change.
\end{abstract}

\section{INTRODUCTION}

\subsection{Framework for LUPA}

The challenging work is creating a set of instrument in connection with land use policy areas with the following research (input) variables: ecosystem (dependent variable), watershed divide or delineation (dependent variable), land use (independent variable), ecosystem-based land use (paired or derived variable), watershed-based land use (paired or derived variable), and integrated environmental management (paired or derived variable) to extract the science-based information (output) which practically highlighted the LUPA classifications, namely: Protection, Production, Settlement and Infrastructure.

The Land Use Policy Area (LUPA) concept model is the intersection of the three elements, namely: (i) ecosystem-based land use is the intersection of the ecosystem and land use elements; (ii) subwatershed-based land use is the intersection of the subwatershed and land use elements; and (iii) integrated environmental management is the intersection of the subwatershed and ecosystem elements.

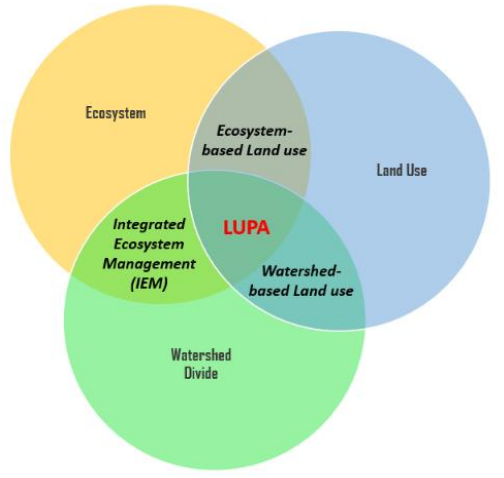

Figure 1. LUPA Concept Model

The intersection is mathematically expressed as the sets of $\{$ LUPA $\} \sim$ \{ecosystem-based land use $\cap \cap$ \{watershed-based land use $\cap$ \{integrated environmental management\}. The 'ecosystem-based land use spatial element' is regarded as a land and water space measurement combining the ecosystem in terms of upland, midland, lowland, coastal dryland, and coastal wetland. Similarly, the 'watershed-based land use spatial element' refers to the land and water space measurement combining the watershed divide and land use. The 'IEM element' in this study refers to the combined ecosystem and watershed 
divide georeferenced information regarded as Integrated Ecosystem Development Planning Unit (Abante, 2021a). The LUPA concept model as shown in Figure 1 offers useful policy options, namely: protection, production, settlement and infrastructure. It points on a given spatial setting.

\subsection{Study Area}

Prieto Diaz is a 5th class municipality of Sorsogon province. It is situated in Sorsogon Province, Region 5, Philippines. Its geographical coordinates are $13^{\circ} 2^{\prime} 30^{\prime \prime}$ North, $124^{\circ} 11^{\prime} 38^{\prime \prime}$ East. It is situated $387 \mathrm{~km}$ southeast of Manila, $50.9 \mathrm{~km}$ southeast of Legazpi City, $31.4 \mathrm{~km}$ east of Sorsogon City. It is part of the southernmost tip of the Bicol Peninsula and Luzon Island.

\subsection{Research problem and objectives}

Uncontrolled developments sometimes caused by lack of analytical maps to picture uncertainties in boundaries and disintegration of information on spaces associated with natural features, watershed divides and ecological zones or imaginary borders of various ecosystems important in land and water resource management. The lack of spatial information to visualize and measure host environments changes that are reliant on geomorphological changes based on topographical conditions viewed as the physical alterations and/or land development.

The study aims to correlate the LUPA elements in finding the answer to the following research questions: (i) where are the unplanned areas near or within the stilt environment or wetland which can symbolize the encroachments of the mangrove forest reserve areas? (ii) what percentage of the land classified as mangrove forest reserve were converted into aquaculture production areas? (iii) what percentage of these aquacultural production areas are idle and/or change back to mangrove forest use?

\section{MAIN BODY}

\subsection{LUPA Changing aspects}

Deforestation and forest degradation (Verburge et.al, 2006) are the most important land use change processes in the Philippines. According to them, despite different policies that aim to reduce logging, recent commercial deforestation, illegal logging, and agricultural expansion pose an important threat to the remaining forest areas. Their model reveals the role of land use for assessing the threats and trade-offs of protecting the designated nature areas. According to them at the national level different scenarios of land use change and implementation of the protected area policy are evaluated and discussed based on a spatially explicit land use allocation model. The land use change models are useful tools to inform protected area management if the selection of the model approach is based on the research and policy questions at the appropriate scale (Verburge et.al, 2006).
2.1.1 Land Resource: Land is a fundamental material resource and the primary platform for economic and other social activities (Corpuz, 2013), laying emphasis on the way land is used and how it is intended to be used are integral components of human development. A land use policy or a land use plan defines the ways by which land should be used (Corpuz, 2013). It directly affects the value of land which is related to its productive potential. Land property rights, therefore, reflect the right to extract value from land, based on how land can be utilized in a socially productive and acceptable manner (Corpuz, 2013). The study disclosed that the land use policies are affecting human development in the Philippines (Corpuz, 2013). The current state of land use policies provides emphasis on the practicality to begin identifying and describing land use policies (Corpuz, 2013). The land use plans and policies should be viewed by planners as well as political leaders as only part of a set of instruments to direct or influence land-based activities and development (Corpuz, 2013).

The modeling of the potential impacts of the past and future (Estoque \& Murayama, 2012) using Remote sensing-technology to analyze the satellite images for years: 1988, 1998 and 2009 resulted to visualization of land use/cover changes on the ecosystem services of Baguio city, the Philippines. The loss of forest cover which highlighted great pressure of urbanization (Estoque \& Murayama, 2012; Abante \& Abante, 2018). The authors concluded that there is a need to strengthen the proper implementation of policies in order to maintain and improve ecosystem services (Estoque \& Murayama, 2012).

\subsection{Land Condition}

The municipality is characterized by the topography with the highest elevation of not more than 300 meters mountain ranges on the west and sloping uplands, alluvial plain and beautiful seascapes, seagrass bed and mangrove forest eastern part of the central low-lying areas of the municipality surrounded by RapuRapu strait and the Pacific Ocean. (Abante, 2021)

2.2.1 Landscape and Seascape: The landscape and seascape of Prieto Diaz is hilly to rolling upland down to the alluvial flat terrain occupies a total land area of 4,767 hectares based on RCMBS in 2014. The municipal fishing ground, which measures $15 \mathrm{~km}$ from the coastlines have an approximate area of $31,754.5178$ ha and 3,806.4403 ha. It has shallow waters where the coral reefs and Halabang Lapiz, Montufar and Bingay Points (geographical names used for oceanographers), BFAR watchtower are located. This location information is also used for fish forecasting available on the internet. It is a modern technique to find out what kind of fishing will be in Montufar Point or Bingay Point in the case of Prieto Diaz. This prediction considers the weather, moon phase, water temperature, and seasonal activity of the fish. This geographical information is also essential in improving ecotourism activities on the coast of Prieto Diaz. (Abante, 2021b)

2.2.2 Watershed and Ecosystem imaginary border: The watershed is an area of land that serves as a catchment for water (Bajjali, 2018) where the surface water enters a common outlet forming a lake, stream, or wetland which infiltrates into the groundwater. The watershed as a hydrologic unit is fundamental to examine the movement, distribution, and quality and quantity of water as a technique essential to properly manage, conserve, and plan the natural resources (Bajjali, 2018). 
The ecosystem main variable is a dependent variable inspired by delineation of ecological zones (Bailey,1983) as a means of developing reliable estimates of ecological zones

\subsubsection{IEM and IE-DPU}

The integrated environmental management (IEM) strategy set off the governance-oriented programs (Guiang, 2013) support the vision, mission, and objectives as an important and much-needed innovation for environment and natural resources management in the Philippines. The steps and processes resulting in agreements facilitate the integration of different sectors and local government interventions in a watershed-ecosystem (Guiang, 2013). The replication of the IEM scales up to improve capacities, policies, support systems, budgetary process, and other preparatory activities are underway (Guiang, 2013). The country needs to ensure ecological stability with effective conservation of biodiversity and critical habitats, as well as mitigate the increasing risks and damages from climate change-related natural and man-made calamities (Guiang, 2013).

Figure 2 is a watershed divide-based politico-administrative boundary regarded as Integrated Ecosystem Development Planning Unit (IE-DPU) that considers the basic political units, naturally defined decision units and roads following the course of some ridges, coastlines and reefs enrich basic political units based on political boundary survey to simplify: (i) land use policy areas stated in the comprehensive land use plans, and (ii) zoning regulations. The municipality landscape and seascape measure $5,286.0409$ ha based on DENR land survey records. The upland and midland landscape of Prieto Diaz is hilly and rolling terrains while the lowland and dry land coastal area is characterized by alluvial flat to gently undulating topography with deranged surface waters and drainage systems. There are three (3) surface rivers in the municipality namely the Ibingan River, Guma River, and Bangui River. Guma River is a source of potable water and irrigation in Barangay Calao. Ibingan River could also be a source of irrigation and potable water in the municipality while the Bangui River is used only for irrigation. There are also ten (10) creeks in the municipality. Coastal waters that extend from Barangay Carayat to Barangay Talisayan are used for fishing, swimming, and other recreational activities. (Abante, 2021a)

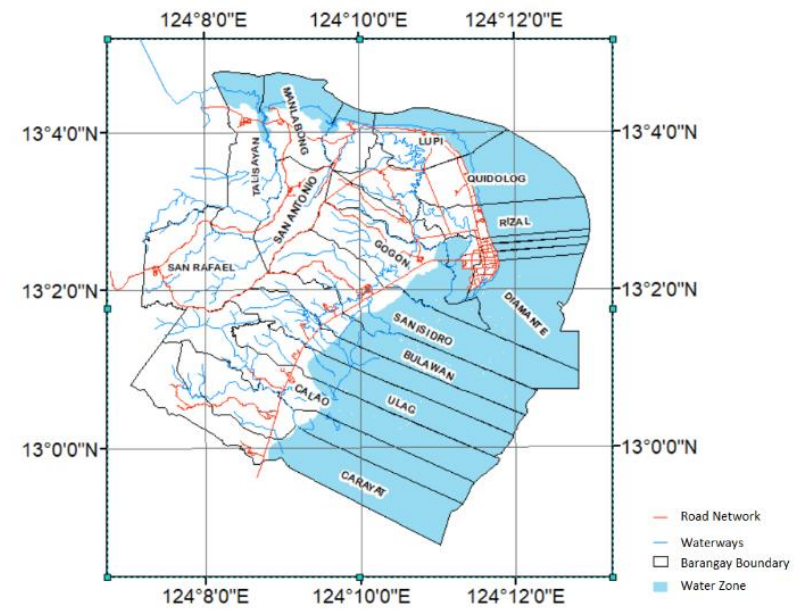

() Reference from Pb-05-000042-D Political Boundary Survey of Prieto Diaz. Approved on May 28, 2015. DENR-Legazpi City

(C) Reference from research data (Abante, 2021a)

(c) OpenStreetMap contributors

Figure 2. Prieto Diaz Politico-Administrative Boundary and Integrated Ecosystem Development Planning Unit (IE-DPU)

\subsection{Methodology}

The LUPA process flow as shown in Figure 3 explains the steps to answer the research questions. GIS technique was applied to assess and process the ecological zone or imaginary border assessment where the result.

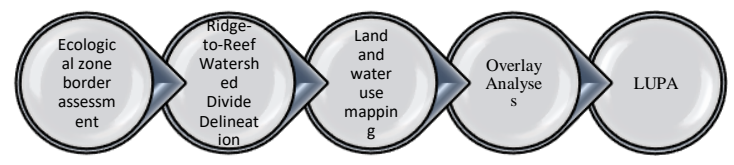

Figure 3. LUPA process flow

Similarly, the same tool was used to assess and process the ridgeto-reef watershed divide delineations. Moreover, the land and water use mapping and processing were carried out using the same technique in ArcGIS platform. The land and water use map disclosed the delineations of the following: agricultural use, aquaculture and fishery use, mangrove forest reserve areas, socialized housing zone, special use, urban and urban use areas, utilities and facilities and water use. GIS overlay and geoprocessing of paired variables were carried out to extract the following target inputs to assess the LUPA result: ecosystembased land use overlaid or paired data, watershed-based land use overlaid or paired data, and integrated ecosystem management overlaid or paired data. The results of paired elements or variables characterizes the LUPA overlaid result.

\subsubsection{Ecological zone border assessment}

The ecological zones within a geographical framework of enclosed space or polygon (Abante, 2021a,b,c), these are: upland (200 $\mathrm{m}$ and above), mid-land (100 to $200 \mathrm{~m}$ ), lowland (10 to 100 $\mathrm{m}$ ), coastal dryland (band of dry land with 0 to $10 \mathrm{~m}$ ) and coastal wetland (water and submerged land below zero or submerged area wherein terrestrial processes and uses directly affect oceanic processes and uses, and vice versa) is an enclosed area solely delineated to capture the mangrove swamps, brackish water ponds, nipa swamps, estuarine rivers, sandy beaches, seagrass area and shallow coral reefs of the municipality.
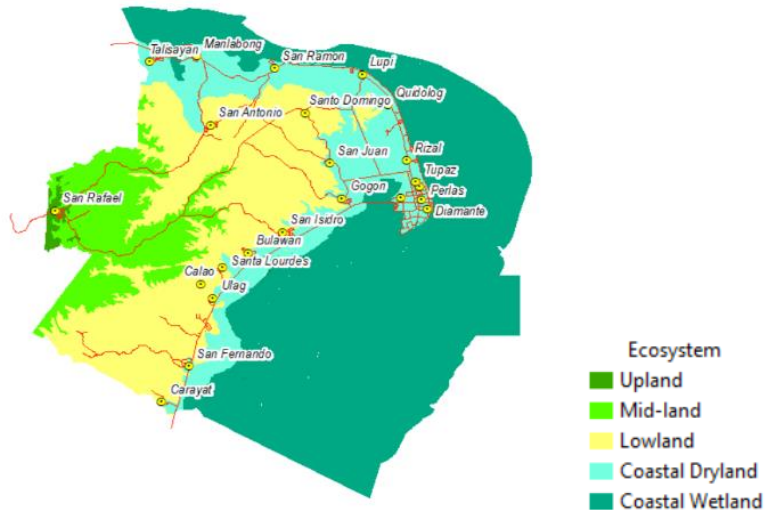

() Reference from research data (Abante, 2021a) () OpenStreetMap contributors

Figure 4. Ecosystem (ecological zone) element

The ecological zone assessment reveals the coastal resources as shown in Figure 4, these are: (i) coastal wetland has the largest ecosystem in Prieto Diaz covering almost $50 \%$ of the territorial jurisdiction of the local government unit, (ii) lowland comprise embody almost $25 \%$ of the total area, (iii) the combined area for agricultural and aquacultural use almost encompass the 
remaining $25 \%$ land of the municipality, and (iv) upland covers insignificant size of land.

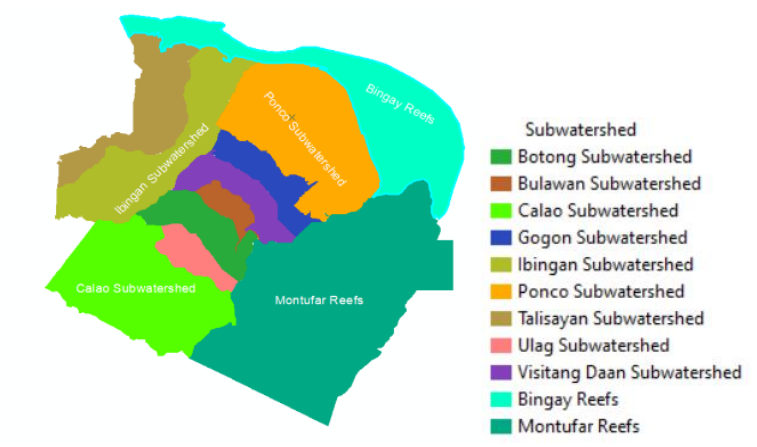

(c) Reference from research data (Abante, 2021a,b)

Figure 5. Subwatershed spatial (polygon) element

2.3.2 Ridge-to-reef divide delineation: The watershed divide variable in this study features the delineation which starts at the highest points on the landscape, peaks and ridges lines that divide one drainage from another. The ridge-to-reef delineation reveals the following subwatershed as shown in Figure 5. Montufar and Bingay Reefs have the largest ecological zone followed by Ponco, Calao and Ibingan subwatershed. Other sub-watersheds are smaller in size compared to the abovementioned subwatershed. The nine ridgelines delineation were named after the river where water drains: Bogtong, Bulawan, Calao, Gogon, Ibingan, Ponco, Talisayan, Ulag, Visitang Daan; and (ii) delineation of Bingay and Montufar Reefs (Abante, 2021b).

2.3.3 Land and water use mapping: The land (and water) use main variable features the dependent variable denoting the areas prone to physical changes within the study area caused by major socioeconomic activities (land use) that happen there which are denoted by polygons as shown in Figure 6 or series of operations on land which are carried out by humans or vegetated either natural or planted areas or water use (including similar surfaces) which are also counted as land cover.

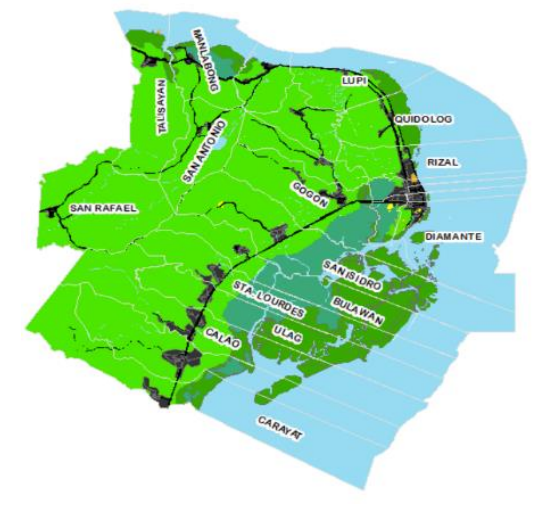

Land Use

$\square$ Agricultural Use

Aquacultural _Fishery Use

Mangrove Forest Reserve

$\square \mathrm{SHZ}$

$\square$ Special Use

- Urban and Urban Use

- Utilities/Facilities

Water Use

(C) Reference from research data (Abante, 2021a,b)

() OpenStreetMap contributors

Figure 6. Land and Water Use, 2021

The land and water use map disclosed that the combined area of agricultural and aquacultural uses cover $51 \%$ production areas of the entire land and water use of the municipality. The combined mangrove forest reserve areas and water use is $44.7 \%$ protection areas. The remaining $4.3 \%$ is distributed to urban and urban uses, special uses, socialized housing zones, utilities and facilities.

\subsection{Overlay Analysis}

2.4.1 Ecosystem-based land use supply analysis: Table 1 disclosed the matrix after carrying out an overlay analysis of ecosystem and land use paired variables. A denotes agricultural use. Aq denotes the aquaculture \& fishery use. MF denotes the mangrove forest reserve areas. 'Sh' denotes the socialized housing zone. Sp denotes the special uses. Ur denotes the urban and urban uses. Ut denotes the utilities and facilities. W denotes the water use.

\begin{tabular}{|c|c|c|c|c|c|c|c|c|}
\hline \multicolumn{9}{|c|}{ Ecosystem-based Land Use by Ha } \\
\hline Ecosystem & A & $\mathrm{Aq}$ & MF & $\mathrm{Sh}$ & $\mathrm{Sp}$ & $\mathrm{Ur}$ & Ut & $\mathrm{W}$ \\
\hline $\begin{array}{l}\text { Coastal } \\
\text { Wetland }\end{array}$ & 21 & 446 & 805 & 0.2 & 0.5 & 0.04 & 3 & 2,643 \\
\hline $\begin{array}{l}\text { Coastal } \\
\text { Dryland }\end{array}$ & 882 & 40 & & 2 & 3 & 117 & 62 & 18 \\
\hline Lowland & 1,800 & & & 1 & 0.4 & 85 & 27 & 26 \\
\hline Mid-land & 776 & & & & & & 9 & 3 \\
\hline Upland & 40 & & & & & 3 & 1.6 & 0.1 \\
\hline
\end{tabular}

Table 1 - Ecosystem-based Land Use Supply in Ha

2.4.2 Sub-watershed -based land use supply analysis: Table 2 disclosed the matrix after carrying out an overlay analysis of subwatershed and land use paired variables. A denotes agricultural use. Aq denotes the aquaculture \& fishery use. MF denotes the mangrove forest reserve areas. 'Sh' denotes the socialized housing zone. Sp denotes the special uses. Ur denotes the urban and urban uses. Ut denotes the utilities and facilities. $\mathrm{W}$ denotes the water use.

\begin{tabular}{|c|c|c|c|c|c|c|c|c|c|}
\hline \multicolumn{2}{|c|}{ Subwatershed } & A & $\mathrm{Aq}$ & MF & $\mathrm{Sh}$ & $\mathrm{Sp}$ & Ur & Ut & $\mathrm{W}$ \\
\hline \multirow{9}{*}{$\frac{\mathbb{8}}{\mathbb{D}}$} & Botong & 207 & 63 & & & & 15 & 5 & 3 \\
\hline & Bulawan & 99 & & & & & & 2 & 4 \\
\hline & Calao & 839 & 25 & 68 & & & 649 & 15 & 7 \\
\hline & Gogon & 204 & 389 & & & & & 3 & 4 \\
\hline & Ibingan & 660 & 30 & 272 & & & 12 & 22 & 25 \\
\hline & Ponco & 760 & 122 & 246 & 2 & 4 & 84 & 40 & 21 \\
\hline & Talisayan & 437 & 9 & 50 & & & 8 & 8 & 5 \\
\hline & Ulag & 118 & 302 & & & & 12 & 3 & \\
\hline & $\begin{array}{l}\text { Visitang } \\
\text { Daan }\end{array}$ & 188 & 44 & & 1 & & 9 & 6 & 3 \\
\hline \multirow{2}{*}{ 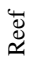 } & Bingay & 7 & & 81 & & & & & 982 \\
\hline & Montufar & & 124 & 555 & & & & & 1.636 \\
\hline
\end{tabular}

Table 2 - Sub-watershed -based Land Use Supply in Ha

2.4.3 IEM-based land use supply analysis: Table 3 disclosed the matrix after carrying out an overlay analysis of subwatershed and ecosystem paired variables. $\mathrm{U}$ denotes the upland. $\mathrm{M}$ denotes the midland. L denotes the lowland. D denotes the coastal dryland. W denotes the coastal wetland. Bi denotes the Bingay reefs. Mo denotes the Montufar reef. 


\begin{tabular}{|c|c|c|c|c|c|c|c|c|}
\hline \multicolumn{2}{|c|}{ Watershed Divide } & $\mathrm{U}$ & $M$ & $\mathrm{~L}$ & $\mathrm{D}$ & $\mathrm{w}$ & $\mathrm{Bi}$ & Mo \\
\hline \multirow{6}{*}{ 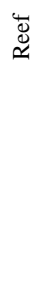 } & Bingay & & & & & & 1,069 & \\
\hline & Montufar & & & & & & & 2,316 \\
\hline & Botong & & 83 & 82 & 62 & 58 & & \\
\hline & Bulawan & & 5 & 73 & 23 & 3 & & \\
\hline & Calao & & 200 & 610 & 112 & 96 & & \\
\hline & Gogon & & & 157 & 51 & 39 & & \\
\hline \multirow[t]{5}{*}{ 兽 } & Ibingan & 30 & 321 & 274 & 127 & 31 & & \\
\hline & Ponco & & & 347 & 543 & 164 & & \\
\hline & Talisayan & 15 & 134 & 165 & 148 & 53 & & \\
\hline & Ulag & & 14 & 93 & 20 & 36 & & \\
\hline & $\begin{array}{c}\text { Visitang } \\
\text { Daan }\end{array}$ & & 30 & 138 & 38 & & & \\
\hline
\end{tabular}

Table 3 - Integrated Environmental Management Inventory in $\mathrm{Ha}$

\subsection{Results and findings}

2.5.1 LUPA Overlay Result: The concept model analysis steers the geospatial information modeling for LUPA in this study which carried the intersections of the paired variables: ecosystem-based land use, subwatershed-based land use and integrated environmental management as variating inputs to process by extracting the science-based information (overlay output) which practically highlighted the LUPA classification: Protection, Production, Settlement and Infrastructure as shown in Figures 7 and 8.

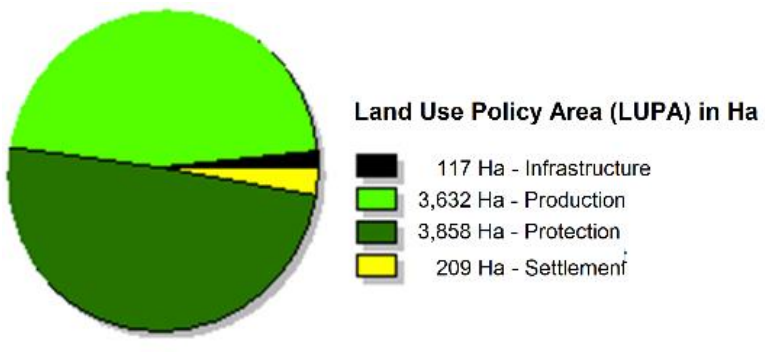

(c) Reference from research data (Abante, 2021a)

Figure 7. LUPA Chart

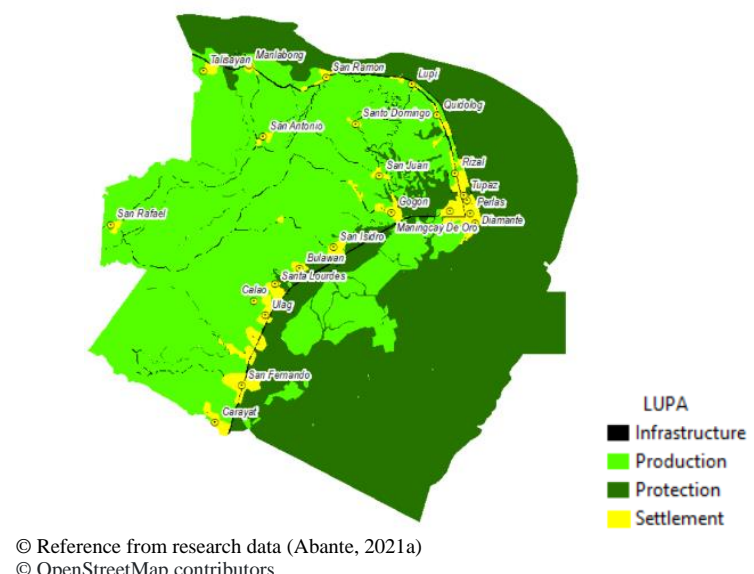

(c) OpenStreetMap contributors

Figure 8. LUPA Map, 2021
2.5.2 Unplanned areas: The study disclosed the unplanned areas in terms of the following but not limited to: (i) houses built near or within the stilt environment or wetland within the forest mangrove reserve areas, (ii) existing aquacultural use, Bigaho Island tourism activity that presently operated by private individual, (iii) coconut plantation in Balumbon Island suitable for mangrove natural growth, (iv) idle (mudflats) aquacultural uses, and (v) rice and coconut plantation within the intertidal zone within the protection forest based on land classification map.

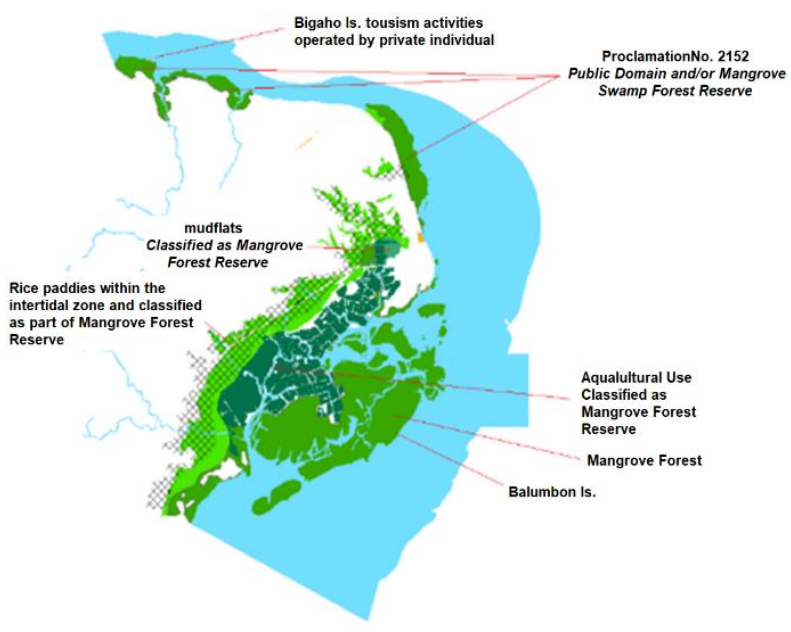

() Reference from research data (Abante, 2021a,b)

Figure 9. Unplanned areas within the protection zone

This study highlights the following major land conversion issues within the mangrove forest reserve areas to aquacultural use based on the Republic Act No. 8550 where fishery operations involving all forms of raising and culturing fish and other fishery species in fresh, brackish and marine water are part of the law which makes provision for the management and conservation of fisheries and aquaculture in the Philippines and the reconstitution or establishment of fisheries institutions both at the national and local level to achieve food security. Although, Prieto Diaz protects the rights of fisherfolk, specially of the local communities with priority to municipal fisherfolk giving them preferential use of the municipal waters, controlling the conversion and to limiting access to the fishery and aquatic resources remain an issue in some parts of the municipality as shown in figure 9 .

2.5.3 Preparedness level of significance: To achieve a stable and sustainable development in the municipality spatial information on risk (Abante, 2021c) as shown in Figure 10a, preparedness (Abante, 2021a,c) as shown in Figure 10b, and integrated ecosystem planning unit (as a decision unit) as shown in Figure 2 were integrated into the land use and water use plan adhering the preferred development thrust and spatial development framework for the next ten years.

To get prepared or advance preparedness, the following LUPA must be implemented: (i) protection areas intend to achieve environmental stability and ecological integrity to ensure stability and sustainable utilization and conservation of some areas with aesthetic, educational, cultural and historical significance; (ii) production areas are the most sustainable and equitable to develop for productive activities that could meet the 
requirements for food security and sufficiency; (iii) settlement development aims to ensure the present and future generation to effectively integrate activities within general residential areas to allow efficient movement of the Prieto Diaznon and the production of commodities through the provisions of stable and safe built environment for living and making a living with basic infrastructure and access to social services; and (iv) Infrastructure development seeks to provide basic services and foster economic to obtain an efficient, responsive, receptive, safe and ecologically friendly built environment that covers critical infrastructure.

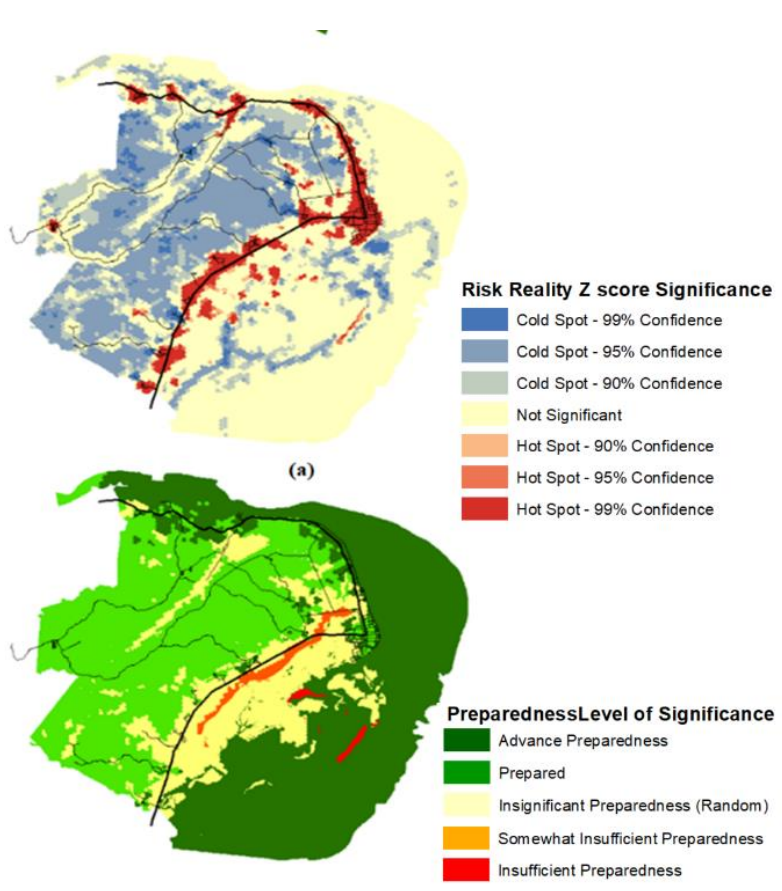

(b)

() Reference from research data (Abante, 2021a,b,c) (C) OpenStreetMap contributors

Figure 10. Parameters for land use reversion

2.5.4 Local development spatial framework: Table 4 provides a holistic view of land and water utilization to direct the 10 -year planning period consistent with the principles of stable and sustainable development in Prieto Diaz. The municipality shall adopt the allocation pattern that promotes and ensure the preferred development option and spatial framework. It was a structured plan in matrix form to guide land and water developments of the municipality. It is a translation of spatial dimensions and allocations of the various land and water resources indicating the desired development options and spatial framework within the watershed divide-based politicoadministrative boundary as shown in Figure 2, regarded as integrated ecosystem development planning unit (Abante, 2021a) that considers the basic political units, naturally defined decision units and roads following the course of some ridges, coastlines and reefs enrich basic political units based on political boundary survey to simplify the land use policy areas and zoning regulations.

\begin{tabular}{|c|c|c|c|}
\hline $\begin{array}{l}\text { Ridge-to- } \\
\text { reef } \\
\text { ecosystem }\end{array}$ & $\begin{array}{c}\text { Ridge to Reef Conservation } \\
\text { Enterprise Development } \\
\text { Thrust }\end{array}$ & $\begin{array}{c}\text { Integrated Ecosystem } \\
\text { Management Approach } \\
\text { Spatial Development } \\
\text { Framework }\end{array}$ & LUPA \\
\hline Upland & $\begin{array}{l}\text { Water security development } \\
\text { Food security development } \\
\text { Agroforestry development } \\
\text { Stingless Honey Tourism } \\
\text { development }\end{array}$ & $\begin{array}{l}\text { Integrated Ecosystem } \\
\text { Management Approach } \\
\text { Spatial Development }\end{array}$ & $\begin{array}{l}\text { Production } \\
\text { Settlement } \\
\text { Infrastructur } \\
e\end{array}$ \\
\hline Midland & $\begin{array}{l}\text { Water security development } \\
\text { Food security development } \\
\text { Agroforestry development }\end{array}$ & $\begin{array}{l}\text { Integrated Ecosystem } \\
\text { Management Approach } \\
\text { Spatial Development }\end{array}$ & $\begin{array}{l}\text { Production } \\
\text { Settlement } \\
\text { Infrastructur } \\
e\end{array}$ \\
\hline Lowland & $\begin{array}{l}\text { Food security development } \\
\text { Agroforestry development } \\
\text { Cave Protection } \\
\text { Buffer/Greenbelt protection } \\
\text { and tourism development }\end{array}$ & $\begin{array}{l}\text { Urban development } \\
\text { Integrated Ecosystem } \\
\text { Management Approach } \\
\text { Spatial Development }\end{array}$ & $\begin{array}{l}\text { Production } \\
\text { Settlement } \\
\text { Infrastructur } \\
e\end{array}$ \\
\hline $\begin{array}{l}\text { Dryland } \\
\text { (Coastal) }\end{array}$ & $\begin{array}{l}\text { Food security development } \\
\text { Agroforestry development } \\
\text { Foreshore (Beach, salvage } \\
\text { zone) Protection and } \\
\text { ecotourism development }\end{array}$ & $\begin{array}{l}\text { Integrated Ecosystem } \\
\text { Management Approach } \\
\text { Spatial Development }\end{array}$ & $\begin{array}{l}\text { Production } \\
\text { Settlement } \\
\text { Infrastructur } \\
e\end{array}$ \\
\hline $\begin{array}{l}\text { Wetland } \\
\text { (Coastal) }\end{array}$ & $\begin{array}{l}\begin{array}{l}\text { Island and } \\
\text { rehabilitation, } \\
\text { and conservation }\end{array} \\
\begin{array}{l}\text { Mangrove } \\
\text { rehabilitation, and }\end{array} \\
\begin{array}{l}\text { production } \\
\text { conservation }\end{array} \\
\text { Footection, }\end{array}$ & $\begin{array}{l}\text { Integrated Ecosystem } \\
\text { Management Approach } \\
\text { Spatial Development } \\
\text { enterprising development }\end{array}$ & $\begin{array}{l}\text { Protection } \\
\text { Production } \\
\text { Infrastructur } \\
e\end{array}$ \\
\hline $\begin{array}{l}\text { Municipal } \\
\text { Waters } \\
\text { (Inland) }\end{array}$ & $\begin{array}{l}\text { Riverbank / Legal easement } \\
\text { protection and ecotourism } \\
\text { development }\end{array}$ & $\begin{array}{l}\text { Integrated Ecosystem } \\
\text { Management Approach } \\
\text { Spatial Development }\end{array}$ & Protection \\
\hline $\begin{array}{l}\text { Municipal } \\
\text { Waters } \\
\text { (Fishing } \\
\text { ground) }\end{array}$ & $\begin{array}{l}\text { underground rivers, shallow } \\
\text { waters (coral reefs), } 15-\mathrm{km} \\
\text { fishing ground protection } \\
\text { Food Security development }\end{array}$ & $\begin{array}{l}\text { Integrated Ecosystem } \\
\text { Management Approach } \\
\text { Spatial Development }\end{array}$ & Protection \\
\hline
\end{tabular}

Table 4. Structured plan based on preferred development option and spatial framework

\subsection{LUPA Model}

The Land Use Policy Area LUPA model as a stratagem can earnestly sought for the highest land use regulations, monitoring, and evaluation of protection, production, settlement, and infrastructure areas. It hints at providing information where to start reversion if necessary to continue stable food production while protecting the sensitive environment. Figure 10a shows the seven-risk hotspot level of significance risk reality (Abante, 2021a,c), and (ii) the five-level of preparedness to realize the preferred development thrust "Ridge to Reef Conservation Enterprise Development" and spatial development framework "Integrated Ecosystem Management Approach Spatial Development" (Abante, 2021c).

2.6.1 Protection areas: Protection of land and water use refers to the use of land primarily for rehabilitation, conservation, and protection purposes and the promotion of the country's ecological and life-support systems. On the other hand, protected 
areas refer to portions of land set aside by reason of their unique physical and biological significance, managed to enhance biological diversity, and protected against destructive human exploitation. It shall apply to all lands, whether public, private, government-owned, and/or in the possession of individuals, communities, or groups of people, to guide and govern the use, allocation, and management of land and water resources, including such activities that bear impact on said resources.

2.6.2 Production areas: Policy interventions and impact in production areas: (i) upland - The production land use in the upland area refers to the direct and indirect utilization of land to generate outputs resulting from the following activities: agricultural, agroforest, energy resource development, stingless honeybee industry, and ecotourism. The policy recommendations for the upland production areas are direct and indirect utilization of land for Agriculture or Agroforestry, crop production, energy development, and Stingless honey farm tourism with proper mitigation measures and all-encompassing enterprising in San Rafael; (ii) mid-land - areas primarily geared to produce food and cash crops, or the extraction of natural resources for their economic value. These areas have relatively few constraints to their continuing use and can sustain intensive and multiple uses. The production land use refers to the direct and indirect utilization of land to generate outputs resulting from the following activities: agricultural, agroforest, and farm tourism. The policy recommendations for the mid-land are direct and indirect utilization of land for agriculture or agroforestry, crop production, farm tourism with proper mitigation measures and all-encompassing enterprising, San Rafael, San Isidro, Talisayan, Bulawan, Sta Lourdes, Ulag, Calao, and San Fernando; (iii) low land - monitor the premature or illegal conversion of prime agricultural areas or alter the physical characteristics of agricultural lands to render them suitable for non-agricultural purposes without an approved order of conversion from the DAR Secretary. Conversion of prime agricultural lands to non-agricultural areas or special uses may be allowed upon approval by the DAR or DA; (iv) Coastal dryland - the Production areas in the dry land are fish, seagrass, and seaweed by-product food processing. The policy recommendations for the dry land are as follows: (a) EIA assessment is mandatory to non-conforming land and water uses because sensitivity to climate variability and change is possible, (b) preparedness is mandatory to conforming to somewhat nonconforming land and water uses because sensitivity to climate variability and change is somewhat possible, (c) aid for food producers and production areas are obligatory, (d) moderate to near 0-Risk development (Abante, 2021c) is tolerable but mitigation is obligatory in production areas including urban use areas, (e) protection and conservation of all food production areas, beaches, foreshore and salvage areas is mandatory, (f) rehabilitation, protection and conservation of production areas in upland, midland, lowland, coastal dry land and wetland areas, (g) provision of a comprehensive drainage system integrating the DPWH flood control and NIA maintenance of floodgates, irrigation canals and Ibingan dam to avoid flooding in food processing facility sites and other production and prime agricultural areas. Seagrass Rehabilitation, conservation and enterprising; and (v) Coastal wetland - the Production areas in the wetland are fishing and production of seagrass and seaweed or the extraction of natural resources for their economic value. The policy recommendations for the wetland are as follows: (a) protection and conservation of all food production areas, beaches, foreshore and salvage areas is mandatory, (b) rehabilitation, protection and conservation of production areas in upland, midland, lowland, coastal dry land and wetland areas, and (c) provision of a comprehensive drainage system integrating the DPWH flood control and NIA maintenance of floodgates, irrigation canals and Ibingan dam to avoid flooding in food processing facility sites and other production and prime agricultural areas. Seagrass Rehabilitation, conservation and enterprising. Special utilization of coastal area (dry land or wetland) must be guided by: (a) areas vegetated by mangroves and 100-year old mangrove species shall not be converted to other use; (b) areas that meet all the accepted criteria on the stability of elevation, soil type, soil depth, topography, idle fish pen (aquaculture) within the mangrove forest areas may be used for special uses such as mangrove eco-park and recreation for ecotourism uses, or bird sanctuary, and (c) reversion of alienable and disposable lands to mangrove forest may be endorsed by concerned LGU after due consultations with the affected parties may be authorized by congress upon recommendation of the DENR Secretary.

2.6.3 Human settlement/resettlement areas: The human settlement/resettlement areas for development refers to the existing settlement sites located in stable (or safe) built environments or proposed resettlement sites. The following policies are: (a) mitigation and improvement of present settlement to advance preparedness in barangay San Rafael; (b) mitigation and improvement of present settlement to advance preparedness in barangay San Rafael, San Isidro, Talisayan, Bulawan, Sta Lourdes, Ulag, Calao, and San Fernando; (c) Nobuild zone refers to a definitive area on the coastal (intertidal) or foreshore or salvage areas for which only limited types of temporary use may be permitted upon securing a temporary use permit and upon payment of the pertinent fees/lease for which the temporary use must be strictly monitored by the local government unit, and remove immediately by permitted users upon expiry of the permitted temporary use periodic; and (d) relocating the exposed families or removing undesired developments in stilt environments and reverting to its highestbest land or water use hints at a balanced and sustainable development.

2.6.4 Infrastructure: The infrastructure areas are devoted to major infrastructure and utility systems. Under the road category are: (a) Roads and bridges, (b) economic infrastructure such as markets and slaughterhouse, (c) social infrastructure such schools, hospitals, day care center, recreational facilities, cemeteries, (d) administrative and institutional facilities such as municipal hall, provincial, regional and national offices, barangay halls, police stations, fire stations, (e) utility facilities such as power substation, telecommunication towers, irrigation facilities, Ibingan dam, solid waste disposal facilities, and (f) transport facilities such as Prieto Diaz Wharf in Talisayan, public transport terminals, and loading and unloading areas. The policy recommendations for infrastructure are: (a) emergency routes (roads that are well designed and constructed), (c) access to health facilities is mandatory, (iii) stable environment and infrastructure such as safe and comfortable evacuation center and temporary relocation sites are desired, (c) quick repair and/or construction of critical infrastructure to stabilize the socioeconomic and local governance is obligatory, and (d) full recovery and rehabilitation across all sectors is desired, (v) provision of a comprehensive drainage system integrating the DPWH flood control and NIA maintenance of floodgates, irrigation canals and Ibingan dam to avoid flooding in emergency routes, institutional areas, socio-economic support facilities sites, and critical infrastructure sites. 


\section{CONCLUSION}

The authors concluded that land use policy areas will relatively change as land use changes which is also seen reliant on the impacts of climate change. The study proved that there is a need to contextualize the highest-best land and water use using the integrated ecosystem development planning unit (decision unit) to allow conservation enterprising activities within the mangrove forest reserve areas or forest protection zone which have a practical significance to achieve food security although it may have negative and/or practical implications. The practical implication of the study is the result can be used to further examine and contextualize the carrying capacity as part $\mathrm{f}$ the instrument to quantity risk realities and insignificant preparedness level in a sensitive host environment allowing just and sustainable enterprising activities on rice production areas within the intertidal zone or the sensitive space utilized for aquaculture and fisheries to ensure stable and sustainable development and land and water resource management.

\section{ACKNOWLEDGEMENTS}

The worthwhile experiences and immense knowledge shared and gained from the extension services on the project "Technical and Training Assistance on the Formulation of the Prieto Diaz Comprehensive Land Use Plan, Year 2021-2030" would not have been realized and achieved without the valuable support of several groups, agencies, institutions, and heads of offices. We especially acknowledge the LGU counterpart Technical Working Group for the informative discussions and the provision of necessary documents. The various multi-sector stakeholders who became part of the consultative discussions for the completion of this project are likewise gratefully acknowledged.

Lastly, for all that we are, and all that we could ever be, we give thanks to God who made all these possible.

\section{REFERENCES}

Abante, A. M. R., 2021a: Manuscript on GIS Model to Contextualize the Advanced Preparedness and Adaptive Capacity for DRRM. Bicol University.

Abante, A. M. R., 2021b: Reintroducing the GeoNames that features the land and water near the Montufar and Bingay Points in Prieto Diaz, Sorsogon, Philippines. International Journal of Computing Sciences Research, 5(1).

Abante, A. M. R., 2021c: Geophilosophical realness of risk: a case study in national housing authority resettlement sites in Albay, Philippines. SN Applied Sciences, 3(4), 1-22.

Abante, A. M. R., Abante, C. G. R., 2018: Sensitive Land Use Planning, Malinao, Albay, Philippines. In IOP Conference Series: Earth and Environmental Science (Vol. 123, No. 1, p. 012001). IOP Publishing.

Arsanjani, J.J., Barron, C., Bakillah, M., Helbich, M., 2013: Assessing the quality of OpenStreetMap contributors together with their contributions. In Proceedings of the AGILE (pp. 1417).

Bailey, R. G., 1983. Delineation of ecosystem regions. Environmental management, 7(4), 365-373.
Bajjali, W., 2018. Watershed delineation. In ArcGIS for environmental and water issues (pp. 235-245). Springer, Cham.

Corpuz, A., 2013. Land use policy impacts on human development in the Philippines. Philippines: UNDP.

Estoque, R. C., Murayama, Y., 2012: Examining the potential impact of land use/cover changes on the ecosystem services of Baguio city, the Philippines: a scenario-based analysis. Applied Geography, 35(1-2), 316-326.

Feldmeyer, Daniel, Claude Meisch, Holger Sauter, Joern Birkmann: Using OpenStreetMap data and machine learning to generate socio-economic indicators. ISPRS International Journal of Geo-Information 9, no. 9 (2020): 498.

Guiang, E. S., 2013: A Proposed DENR Road Map for Replicating and Scaling Up of Governance-Oriented Integrated Ecosystems Management.

Novoselov, A., Potravnii, I., Novoselova, I., Gassiy, V., 2016 Conflicts management in natural resources use and environment protection on the regional level. Journal of Environmental Management \& Tourism, 7(3 (15)), 407-415.

Verburg, P. H., Overmars, K. P., Huigen, M. G., de Groot, W. T., Veldkamp, A., 2006: Analysis of the effects of land use change on protected areas in the Philippines. Applied Geography, 26(2), 153-173.

Sato, J. R., 2019: Pending Bill entitled "An Act Instituting the National Land, Water, And Air Use Policy of The Republic of The Philippines, Providing the Implementing Mechanisms Therefore, and for other Purposes". 